"An application of Altman Z-score model to analyze the bankruptcy risk: cases of multidisciplinary enterprises in Vietnam"

\begin{tabular}{|c|c|c|}
\hline AUTHORS & \multicolumn{2}{|l|}{$\begin{array}{l}\text { Diep Thanh Tung } \\
\text { Vo Thi Hoang Phung }\end{array}$} \\
\hline ARTICLE INFO & \multicolumn{2}{|c|}{$\begin{array}{l}\text { Diep Thanh Tung and Vo Thi Hoang Phung (2019). An application of Altman Z- } \\
\text { score model to analyze the bankruptcy risk: cases of multidisciplinary enterprises } \\
\text { in Vietnam. Investment Management and Financial Innovations, 16(4), 181-191. } \\
\text { doi:10.21511/imfi.16(4).2019.16 }\end{array}$} \\
\hline DOI & \multicolumn{2}{|c|}{ http://dx.doi.org/10.21511/imfi.16(4).2019.16 } \\
\hline RELEASED ON & \multicolumn{2}{|l|}{ Friday, 06 December 2019} \\
\hline RECEIVED ON & \multicolumn{2}{|l|}{ Monday, 21 October 2019} \\
\hline ACCEPTED ON & \multicolumn{2}{|l|}{ Wednesday, 27 November 2019} \\
\hline & \multicolumn{2}{|c|}{$(\mathrm{cc}) \overline{E Y}$} \\
\hline LICENSE & \multicolumn{2}{|c|}{$\begin{array}{l}\text { This work is licensed under a Creative Commons Attribution } 4.0 \text { International } \\
\text { License }\end{array}$} \\
\hline JOURNAL & \multicolumn{2}{|c|}{ "Investment Management and Financial Innovations" } \\
\hline ISSN PRINT & \multicolumn{2}{|l|}{$1810-4967$} \\
\hline ISSN ONLINE & \multicolumn{2}{|l|}{$1812-9358$} \\
\hline PUBLISHER & \multicolumn{2}{|c|}{ LLC "Consulting Publishing Company "Business Perspectives" } \\
\hline FOUNDER & \multicolumn{2}{|c|}{ LLC "Consulting Publishing Company "Business Perspectives" } \\
\hline \multirow{2}{*}{ NUMBER OF REFERENCES } & & ニシ: \\
\hline & NUMBER OF FIGURES & NUMBER OF TABLES \\
\hline 50 & 0 & 5 \\
\hline
\end{tabular}

(C) The author(s) 2022. This publication is an open access article. 


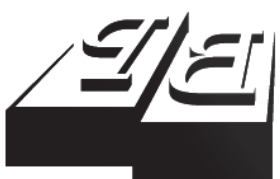

BUSINESS PERSPECTIVES

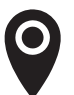

LLC "CPC "Business Perspectives" Hryhorii Skovoroda lane, 10, Sumy, 40022, Ukraine

www.businessperspectives.org

Received on: $21^{\text {st }}$ of October, 2019 Accepted on: $27^{\text {th }}$ of November, 2019

(c) Diep Thanh Tung, Vo Thi Hoang Phung, 2019

Diep Thanh Tung, Ph.D., Tra Vinh University, Vietnam.

Vo Thi Hoang Phung, Tax Department of Soc Trang Province, Vietnam.

\section{AN APPLICATION OF ALTMAN Z-SCORE MODEL TO ANALYZE THE BANKRUPTCY RISK: CASES OF MULTIDISCIPLINARY ENTERPRISES IN VIETNAM}

\begin{abstract}
This study applied Altman Z-score model to assess the bankruptcy risk of a set of multidisciplinary enterprises of various types, mainly small and medium enterprises, with data taken from official financial reports of 180 enterprises in Soc Trang province. The binary logistic regression was employed to assess the impact of non-financial and financial factors on the bankruptcy risk of enterprises. The research findings showed that both the non-financial factors such as business area, types and size of the business, the educational level of managers and executors and other characteristics, and the financial factors (indicators) such as earnings before tax, net profit/equity ratio, earnings before interest and tax/total assets ratio, equity/total debt ratio, affect the bankruptcy risk of enterprises. Predicting the bankruptcy risk and measuring its determinants play an important role not only as an effective managing tool of the business, but also as evidence for policymakers to support the sustainable development of business.
\end{abstract}

Keywords

SMEs, governance, prediction, finance, risk, bankruptcy

\section{JEL Classification G32, G33}

\section{INTRODUCTION}

Vietnam's economy is increasingly integrated and closely related to the regional and global economy once engaging in new generation free trade agreements such as the Comprehensive and Progressive Agreement for Trans-Pacific Partnership, the European Union Vietnam Free Trade Agreement. Such engagement not only opens up many business opportunities for Vietnam, but also entails numerous challenges. According the 2018 Provincial Competitiveness Index Report, $8.3 \%$ of businesses planned to downsize or close down as a result of not being able to adapt to market changes or increasingly intense competition. It was worth noticing that though the rate slightly increased from $8.2 \%$ in 2017 , it was the third highest since the Provincial Competitiveness Index (PCI) survey was introduced in 2005. This even became an alarming issue for local governments in its great efforts to achieve the target of 1 million operational businesses by 2020 set by the Government's Resolution number 35 in 2016 (VCCI and USAD, 2018).

Bankruptcy is one of the most important issues in the finance world of enterprises because it refers to the financial health or stability of business entities (Taffler, 1983). Therefore, enterprises need to forecast the bankruptcy risk in any business decisions (Tam \& Kiang, 1992; Ramana, Azash, \& Ramakrishnaiah, 2012). 
A company's "survival" opportunity can be predicted by using financial report analysis (Vikash, 2018) to have early warnings about financial hardship or bankruptcy risk prediction. From the 60s of the last century, the bankruptcy risk was one of the issues that received great interest. Many studies worldwide have strongly focused on verifying the bankruptcy risk analysis. Among proactive authors, Beaver (1966) and Altman (1968) were seen as pioneers in the applications of financial ratios to predict the bankruptcy risk in empirical studies.

Beaver (1966) used the univariate analysis method through evaluating each individual financial index. However, when indicators were conflicting, it was difficult to conclude. Therefore, Altman (1968) recommended a method of multivariate analysis to overcome this problem and the model was first published on September 1968. Subsequently, Altman, Haldeman, and Narayanan (1977) introduced the bankruptcy prediction model, the $Z$-score model, to overcome the shortcomings of the original model which was followed by $Z^{\prime}$ and $Z^{\prime \prime}$ models. After over fifty years from introducing the initial version of $Z$-score bankruptcy models, this model has become the most well-known method to provide an early warning sign of financial hardship in many studies of scholars and practitioners around the world (Altman, 2018).

Various versions of $Z$-score are calculated to match different characteristics of enterprises. In this study

the authors used the $Z$-score $\left(Z^{\prime \prime}\right)$ index to assess the bankruptcy risk of multidisciplinary enterprises and by types of business. Through the assessment, the study estimated the factors affecting the bankruptcy risk of the enterprises. The research findings were expected to identify the determinants of bankruptcy risk, to serve the decision-making of the enterprises and to suggest an evidence base for governmental agencies to introduce business support policies.

\section{LITERATURE REVIEW}

\subsection{Z-score}

The Z-score model for predicting the probability of bankruptcy was first introduced in 1968 by Edward I. Altman. This model was proved to be accurate in predicting the bankruptcy at a rate of $94 \%$. The initial sample consisted of 33 bankrupt enterprises and 33 enterprises with stable finance in the manufacturing industry (Altman, 1968). The model forecasted relatively accurately up to 2 years before bankruptcy occurred by considering the $Z$-score value of enterprises.

$Z$-score is an index combining 5 different financial ratios with different weights and is applied to equitized enterprises. The original $Z$-score formula is:

$$
Z=1.2 X_{1}+1.4 X_{2}+3.3 X_{3}+0.64 X_{4}+0.999 X_{5} \text {, }
$$

where $X_{1}$ - working capital/total assets, $X_{2}$ - retain earnings/total assets, $X_{3}-$ EBIT/total assets, $X_{4}$ - market value of total equity/book values of total debt, $X_{5}-$ sales/total assets.
Where $Z$-score of greater than 2.99 clearly falls into the "non-bankrupt" sector, those enterprises having a $Z$ below 1.81 are all bankrupt risk. The area between 1.81 and 2.99 is defined as the "zone of ignorance" or "gray area" because of the susceptibility to error classification (Altman, 1968).

Based on the original $Z$-score, Altman developed $Z^{\prime}$ and $Z^{\prime \prime}$ to be applicable to other types of businesses. With model $Z^{\prime}$, the elements were defined as the $Z$-score model, except the $X_{4}$, which used book value of equity leading to a change in the coefficient of variables and the risk of bankruptcy being reclassified. As for the $Z$ "-score model, the difference of the $Z^{\prime \prime}$-score versus $Z$-score and $Z$ "-score models was that the $X_{5}$ variable was not used, specifically as follows:

$$
Z^{\prime \prime}=6.56 X_{1}+3.26 X_{2}+6.72 X_{3}+1.05 X_{4} \text {. }
$$

The $Z^{\prime \prime}$-score can be used for most industries and types of businesses, in which:

- if $Z^{\prime \prime}>2.6$ : enterprises in safe areas, not at risk of bankruptcy; 
- if $1.1<Z^{\prime \prime}<2.6$ : enterprises in the warning zone of bankruptcy risk;

- if $Z^{\prime \prime}<1.1$ : enterprises in a dangerous area with a high risk of bankruptcy.

\subsection{Applications of Z-scores}

There are various studies on $Z$-scores and their applications in business types or industries to measure and predict the bankruptcy risk of enterprises in many nations.

Leonardo and Jaime (2003) concluded that the $Z$-score index had good predictability of bankruptcy risk of Italian manufacturing enterprises. Meanwhile, this index predicted accurately for the textile industry in Pakistan within four years, although this predictable rate gradually decreased over the years when an experimental study on 12 enterprises with financial stability and 9 of these went bankrupt in 20002010 period (Hussain, Ali, Ullah, \& Ali, 2014).

In Sri Lanka, the $Z$-score was also used to predict the bankruptcy risk of seven commercial companies, data taken during the five-year period from 2010 to 2014 (Niresh \& Pratheepan, 2015). In India, Apoorva, Curpod and Namratha (2019) showed a predictable ability of $Z$-score three years in advance when companies went bankrupt.

The reliability and accuracy of the $Z$-score model are still a matter of debate. Odibi, Basit, and Massan (2015) have shown that this model was very suitable for the significance level of 0.000 and the accuracy of Z-score between $86 \%$ and $99.6 \%$ when applied to 34 enterprises including both bankrupt enterprises and enterprises with financial stability in Malaysia during 2010-2014. The accurate prediction rate was $93.8 \%$ before the bankruptcy occurred for Jordanian enterprises operating in non-financial services and industrial services in the period 1990-2006 (Alkhatib \& Bzour, 2011). However, this rate dropped to $81 \%$ when applied to Indian emerging market companies and decreased to $72 \%$ two years before bankruptcy occurred (Bhatt, 2012).

The $Z$-scores are considered as a good tool in "financial health check" and helps financial manag- ers, analysts, investors, to predict the bankruptcy risk in business or the financial sustainability of the enterprises to make rational and prudent decisions (Vikash, 2018; Sulphey \& Nisa, 2013). The Z-score index was also used as an internal criterion to assess the reputation of borrowers or to help investors consider making the decisions (Pradhan, 2014).

The $Z$-scores were not only applied to the evaluation of listed enterprises but also used in evaluating small and medium enterprises. Umiaty and Dinarjad (2018) used Altman's Z-score as a tool to measure the bankruptcy risk between small and medium enterprises in business incubators. In the study of Selassie, Tarekegn, and Ufo (2016), Z-score was employed to analyze the financial issues of small and medium enterprises with a sample of 30 enterprises in the Wolaita Region of Ethiopia operating in three areas of production, service, and trade. Jan and Marimuthu (2015) also used Altman's Z-score model to assess the insolvency of small and medium enterprises in Malaysia. In another study of Milka and Celia (2018), the $Z$-score was applied as the evaluation standard to analyze and predict the financial status of small and medium enterprises from Tuxtepec, Oaxaca in Mexico. Similarly, in the study of Galinoma and Paul (2016), the $Z$-score was also used as a tool to analyze the financial difficulties in the data from financial reports of 102 small and medium enterprises in a developing economy like Tanzania. Altman's $Z$-score model was also one of the three models selected for web-applications to assess the financial health of small and medium enterprises (David \& Lenka, 2012).

In Vietnam, Cuong and Anh (2010) used the $Z$-score model to assess the bankruptcy risk of seafood processing enterprises listed on Vietnam's stock market. The study came out with some recommendations to reduce the bankruptcy risk of seafood processing enterprises and contribute to banks' policies to improve the efficiency of credit risk management in banking operations.

Regarding the financial activities of Vietnamese banks, Duong (2013) applied the Z-score to predict the bankruptcy risk of 36 commercial banks and considered this score as a standard to assess the financial health of businesses and support the banks to make timely responses to changes of the market. 
The $Z$-score can assess the risks of businesses that are indirectly accompanied by the risks of commercial banks when lending (Canh, 2014). The study by Hieu (2015) proposed to use Z-score models as a tool to re-evaluate credit rankings and estimate the probability of the bankruptcy risk of borrowers. The $Z$-score again confirmed in Vietnam that both academic and practical circles were the most widely recognized and used in the world (Hanh \& Hoa, 2016).

The prediction accuracy of the $Z$-score model on the bankruptcy risk was examined in Vietnam. Anh and Hang (2012) examined the reliability of this model with a sample of 293 listed enterprises in Ho Chi Minh City Stock Exchange. Test results showed that Altman's model achieved an accurate forecasting rate of $91 \%$ at one year before the financial exhaustion. This rate dropped to $72 \%$ within two years.

Therefore, through the $Z$-score model which has been studied and widely applied for a long time in many countries around the world, and the results of applied experimental analysis in Vietnam showed that the $Z$-score model still proves superiority in analyzing and evaluating business activities, classifying risk areas, credit ratings, assessing the bankruptcy level of enterprises and being able to apply for an enterprise or a larger number of enterprises in the scale of analysis, for enterprises by many industries, sectors, and by different sizes of capital sources (Van, 2016).

\section{DATA AND METHODS}

For over fifty years since the first introduction of the $Z$-score model, the model has continuously improved. Despite the huge growth in the size and complexity of the global debt market and accounting balance sheet but the $Z$-score models have shown that not only longevity, but is also a predictor accurate on the company's predicament, and also successfully revised for some applications (Altman, 2018).

Besides, the $Z$ model has become simplicity in the calculation, transparency and accuracy consistently over the years, the $Z$ model has been verified and compared to a large number of studies in terms of accuracy of classification and prediction and practice in finance and accounting for over fifty years (Altman, 2018).

The $Z^{\prime \prime}$ model has advantages over other models due to its use for all industrial, manufacturing and non-manufacturers. In addition, the $Z^{\prime \prime}$ model also uses bankruptcy risk prediction for enterprises that are not publicly listed firms and there is no big difference between firms operating in different industries due to no consideration to sales/total assets (Altman, 2018).

This study applied the $Z$-score to assess the bankruptcy risk of a collection of 180 small and medium non-financial enterprises. Unlike the studies which were based on public financial reporting sources of listed companies, it is very challenging to access official data of unlisted enterprises, mainly small and medium enterprises. Within this empirical study, we, therefore, extracted the official data of enterprises from the financial statements of the enterprises submitted to the Tax Authority of Soc Trang Province after ensuring the anonymity principle of enterprises.

The data in this study allowed the empirical experimentation of various scales, multi-types (private enterprises, limited liability companies, jointstock companies), multi-industries (production, trade - service, construction, other industries) of enterprises. Empirically, many of the abovementioned studies applied the $Z^{\prime \prime}$ model of Altman for this kind of enterprise data, which was applied again in this study.

As mentioned, the $Z^{\prime \prime}$ model classifies bankruptcy risks by three categories: $Z$-score of greater than 2.99 clearly fall into the "non-bankrupt" sector, while those enterprises having a $Z$ below 1.81 are all bankrupt. The area between 1.81 and 2.99 is defined as the "zone of ignorance" or "gray area" because of the susceptibility to error classification (Altman, 1968).

However, in this study, to apply a binary logistic regression in the next step, we re-classified the $Z^{\prime \prime}$-scores in only two groups: without bankruptcy risk $\left(Z^{\prime \prime}>2.6\right)$ and with bankruptcy risk $\left(Z^{\prime \prime} \leq 2.6\right)$. This study defined risk of bankruptcy as having both dangerous areas and warning are- 
as because of potential risks. Then, a binary logistic regression model was applied to measure the factors affecting the bankruptcy risk, which was specified as the following equation:

$$
\operatorname{Ln}\left[\frac{P_{0}}{1-P_{0}}\right]=\beta_{0}+\sum_{j=1}^{k} \beta_{j} X_{j}+\varepsilon,
$$

where $P_{0}$ - probability of enterprises at bankruptcy risk, $1-P_{0}$ probability of enterprises not at bankruptcy risk, $X_{j}$ is the independent variable $j$ and $\beta_{j}$ is the respective coefficient of $j$.

Independent variables $\left(X_{j}\right)$ that were expected to affect bankruptcy risk included a number of financial factors and non-financial factors. Based on the elements of the $Z$-score model, the selection of independent variables was statistically significant. And non-financial factors were inherited variables related to the performance of enterprises from previous studies to conduct the analysis as follows:

- Bankruptcy risk (Risk) - dependent variable: the risk of bankruptcy of an enterprise. If $Y=1$, the business is at risk of bankruptcy; if $Y=0$, the business is not in danger of bankruptcy.

- CEO_gender: gender of the executive, 1 if male, 0 if female. There exist two opposite views. First, female CEOs increased the profitability of the company and reduced the level of risk of the business than male CEOs (Khan \& Vieito, 2013). However, there is a perception that a company run by women would be less effective (Inmyxai \& Takahashi, 2010; Amran, 2011; Hsu, Kuo, \& Chang, 2013).

- CEO_edu: education level of the business executive. The education level of managers is an important feature that contributes to the increase in company performance (Cheng, Chan \& Leung, 2010; Huang, 2013; Joh \& Jung, 2016).

- Firm_age: number of years of operation of the enterprise from the establishment to current. There are two opposing views, according to Omondi and Muturi (2013), the longer the business operated, the better it understood its strengths and promoted more to achieve max- imum efficiency. However, the research of Park, Shin, and Kim (2009) showed that the age of the enterprise had a negative impact on enterprise growth and when the enterprise was "getting older," profit would decrease (Elif, 2016).

- Field: business field, including sub-variables:

- Field_man: manufacture sector, 1 if true, 0 if not true;

- Field_com_ser: commercial - service sector, 1 if true, 0 if not true;

- Field_cons: construction sector, 1 if true, 0 if not true;

- Field_other: other sectors, 1 if true, 0 if not true.

- Type: type of establishment of the business, including sub-variables:

- Type_one: single-member limited liability company, 1 if true, 0 if not true;

- Type_more: limited company with two or more members, 1 if true, 0 if not true;

- Type_joint: joint-stock company, 1 if true, 0 if not true;

- Type_private: private enterprise, 1 if true, 0 if not true.

SME: small and medium enterprise, 1 if true, 0 if not true;

EBT: earnings before tax.

- ROE: return on equity.

Profit plays an important role in the business and production activities of the enterprise, both as a goal, as well as a motivation and a condition of existence and development of the enterprise.

- EBIT/TA: earnings before interest and tax (EBIT) to total assets (TA) ratio.

- TE/TD: total equity to total debt ratio. 
These two factors were inherited from Altman $Z$-score model.

Altman's Z-model, like most previous studies, often revolved around analyzing the financial factors of groups: financial leverage, profitability, solvency ..., which were determinants of bankruptcy risk of a business. In this study, the authors put into the model of non-financial factors to assess the impact of these factors on corporate bankruptcy risk.

\section{FINDINGS}

\subsection{Bankruptcy risk of the enterprises}

According to Table 1 and Table 2, among 180 selected enterprises, 53 enterprises in dangerous areas accounted for $29.44 \%, 35$ enterprises in the warning zone accounted for $19.44 \%$ and 92 enterprises in a safe area without bankruptcy risk accounted for $51.12 \%$.

In separate industries, Table 1 showed that enterprises operating in the manufacturing sector were at a higher level of bankruptcy risk than other industries. Their proportions in the highest warning area and dangerous area accounted for $36.84 \%$ and $28.95 \%$, respectively, in the sample. Enterprises in the commercial and service sectors in dangerous areas and the warning ar- ea accounted for $52.17 \%$ totally, while this proportion of construction enterprises was $34.29 \%$. Enterprises operating in other remaining industries, such as education, lottery activities had the lowest level of bankruptcy risk, accounting for $20 \%$ approximately.

The ANOVA test results in Table 2 also showed that there was a statistically significant difference in the bankruptcy risk between fields.

In addition, the statistics in Table 3 indicated that joint-stock companies were at a higher level of bankruptcy risk. 21 of 31 joint-stock companies were at risk of bankruptcy, accounting for $67.74 \%$. The bankruptcy risk was also high for limited liability companies with two or more members. Of 49 limited liability companies with two or more members, 27 were at risk of bankruptcy, accounting for $55.10 \%$. Meanwhile, the proportion of single-member limited liability companies and private enterprises being at bankruptcy risk was lower, accounting for $44.44 \%$ and $21.05 \%$, respectively.

In order to clarify the differences in bankruptcy risk between types of enterprises, the study continued to conduct ANOVA analysis, and the results showed that there were statistically significant differences between limited liability companies with two or more members and private enterprises between the joint-stock and private enterprises.

Table 1. Bankruptcy risks of enterprises by industries

\begin{tabular}{|c|c|c|c|c|c|c|c|c|c|c|}
\hline \multirow{2}{*}{ Bankruptcy risk } & \multicolumn{2}{|c|}{ Manufacturing } & \multicolumn{2}{|c|}{ Commerce - service } & \multicolumn{2}{|c|}{ Construction } & \multicolumn{2}{|c|}{ Other sectors } & \multicolumn{2}{|c|}{ Total } \\
\hline & Obs. & (\%) & Obs. & (\%) & Obs. & (\%) & Obs. & (\%) & Obs. & (\%) \\
\hline Safe zone & 13 & 34.21 & 44 & 47.83 & 23 & 65.71 & 12 & 80 & 92 & 51.12 \\
\hline Warning zone & 11 & 28.95 & 16 & 17.39 & 8 & 22.86 & 0 & 0 & 35 & 19.44 \\
\hline Dangerous zone & 14 & 36.84 & 32 & 34.78 & 4 & 11.43 & 3 & 20 & 53 & 29.44 \\
\hline Total & 38 & 100 & 92 & 100 & 35 & 100 & 15 & 100 & 180 & 100 \\
\hline
\end{tabular}

Table 2. The difference in bankruptcy risk between business fields

Source: Authors' estimation.

\begin{tabular}{|c|c|c|c|c|}
\hline Field & Manufacturing & Commerce - service & Construction & Other sectors \\
\hline Manufacturing & - & 0.1362 & $0.3150^{*}$ & $0.4579^{*}$ \\
\hline Commercial - service & -0.1362 & - & 0.1789 & 0.3217 \\
\hline Construction & $-0.3150^{*}$ & -0.1789 & - & 0.1429 \\
\hline Other sectors & $-0.4579^{*}$ & -0.3217 & -0.1429 & - \\
\hline
\end{tabular}

Note: * significant level at alpha equal to .05 . 
Table 3. The bankruptcy risks by types

Source: Authors' calculation.

\begin{tabular}{|c|c|c|c|c|c|c|c|c|c|c|}
\hline \multirow[t]{2}{*}{$\begin{array}{c}\text { Risk of the bankruptcy } \\
\text { of the business }\end{array}$} & \multicolumn{2}{|c|}{$\begin{array}{c}\text { Single-member } \\
\text { limited liability } \\
\text { company }\end{array}$} & \multicolumn{2}{|c|}{$\begin{array}{l}\text { Limited liability } \\
\text { company with two } \\
\text { or more members }\end{array}$} & \multicolumn{2}{|c|}{$\begin{array}{l}\text { Joint-stock } \\
\text { company }\end{array}$} & \multicolumn{2}{|c|}{$\begin{array}{l}\text { Private } \\
\text { enterprise }\end{array}$} & \multicolumn{2}{|c|}{ Total } \\
\hline & Obs. & (\%) & Obs. & (\%) & Obs. & (\%) & Obs. & (\%) & Obs. & (\%) \\
\hline Safe zone & 45 & 55.56 & 22 & 44.90 & 10 & 32.26 & 15 & 78.95 & 92 & 51.12 \\
\hline Warning zone & 17 & 20.99 & 9 & 18.37 & 7 & 22.58 & 2 & 10.53 & 35 & 19.44 \\
\hline Dangerous zone & 19 & 23.45 & 18 & 36.73 & 14 & 45.16 & 2 & 10.52 & 53 & 29.44 \\
\hline Total & 81 & 100 & 49 & 100 & 31 & 100 & 19 & 100 & 180 & 100 \\
\hline
\end{tabular}

Table 4. The difference in bankruptcy risk between types of enterprises

\begin{tabular}{|c|c|c|c|c|}
\hline Type & Type_one & Type_more & Type_joint & Type_private \\
\hline Type_one & - & -0.1066 & -0.2330 & 0.2339 \\
\hline Type_more & 0.1066 & - & -0.1264 & $0.3405^{*}$ \\
\hline Type_joint & 0.2330 & 0.1264 & - & $0.4669^{*}$ \\
\hline Type_private & -0.2339 & $-0.3405^{*}$ & $-0.4669^{*}$ & - \\
\hline
\end{tabular}

Note: * significant level at alpha equal to .05 .

\subsection{Determinants of bankruptcy risk}

To employ the binary logistic regression, we re-classified the bankruptcy risk (Risk) by two categories. If $Y=1$, the business was at risk of bankruptcy; otherwise, the business was not in danger of bankruptcy. The regression results in Table 3 indicated the correlations between the dependent variable and the independent variables in the general model with statistical significance. Variance inflation factors of independent variables were lower than 2 , small enough to conclude that there was no multicollinearity between variables.

As shown in Table 5, the regression results supported the following findings: that the non-financial factors such as fields, types and size of the business, the educational level of the executors, which belong to the characteristics of the enterprises and the operators, and the financial factors such as Earnings before tax, Net profit/Equity ratio, Earnings before interest and tax/Total assets ratio, Equity/Total debt ratio all affected the bankruptcy risk of enterprises.

Table 5. Determinants of bankruptcy risk in the binary logistic model

Source: Authors' estimation.

\begin{tabular}{|c|c|c|c|c|}
\hline Independent variables & Coefficient (B) & Sig. & $\operatorname{Exp}(B)$ & VIF \\
\hline$X_{1}($ CEO_gender $)$ & 0.309 & 0.706 & 1.362 & 1.265 \\
\hline$X_{2}($ CEO_edu $)$ & $-0.470 * * *$ & 0.001 & 0.625 & 1.323 \\
\hline$X_{3}$ (FIRM_age) & 0.073 & 0.296 & 1.075 & 1.272 \\
\hline$X_{4.1}$ (Field_man) & $2.833^{* *}$ & 0.017 & 16.996 & 1.311 \\
\hline$X_{4.2}($ Field_cons $)$ & 0.813 & 0.352 & 2.254 & 1.436 \\
\hline$X_{4.3}$ (Field_other) & $-2.414^{*}$ & 0.094 & 0.089 & 1.292 \\
\hline$X_{5.1}$ (Type_more) & -0.843 & 0.283 & 0.431 & 1.287 \\
\hline$X_{5.2}($ Type_joint) & $2.946^{* *}$ & 0.016 & 19.039 & 1.446 \\
\hline$X_{5.3}$ (Type_private) & $-1.894^{*}$ & 0.086 & 0.150 & 1.211 \\
\hline$X_{6}(\mathrm{SME})$ & $-13.719 * * *$ & 0.001 & 0.000 & 1.474 \\
\hline$X_{7}(\mathrm{EBT})$ & $-0.062 * * *$ & 0.007 & 0.940 & 1.731 \\
\hline$X_{8}(\mathrm{ROE})$ & $-7.140 * * *$ & 0.008 & 0.001 & 1.093 \\
\hline$X_{9}(\mathrm{EBIT/TA})$ & $-44.593 * *$ & 0.015 & 0.000 & 1.678 \\
\hline$X_{10}(T E / T D)$ & $-3.828 * * *$ & 0.000 & 0.022 & 1.235 \\
\hline Constant & 22.208 & 0.000 & \multicolumn{2}{|c|}{-} \\
\hline $\mathrm{N}$ & 180 & \multicolumn{3}{|c|}{-} \\
\hline-2 Log likelihood & 76.861 & \multicolumn{3}{|c|}{-} \\
\hline Nagelkerke $R$-square & 0.822 & \multicolumn{3}{|c|}{-} \\
\hline Overall percentage (\%) & 90.6 & \multicolumn{3}{|c|}{-} \\
\hline
\end{tabular}

Note: $*, * *, * * *$ significant levels at alpha equal to $.10, .05, .01$, respectively. 


\section{DISCUSSIONS}

The research showed that regarding the characteristics of the executive, the higher educational level of the executive, the lower the bankruptcy risk of the business. This finding was consistent with the evidence of other studies, both in Vietnam and other countries (Hambrick \& Mason, 1984; Jalbert, 2002; Bertrand \& Schoar, 2003; Khoi, Loc, \& Danh, 2008; Nghi \& Nam, 2011; Cheng et al., 2010; Huang, 2013; Joh \& Jung, 2016). However, in our study, the gender of the executive was not significant to be considered as determinants of bankruptcy risk of the business.

For small and medium-sized enterprises, there was an inverse correlation with the dependent variable. It means that small and medium-sized enterprises were at a lower level of bankruptcy risk than large-sized ones. Criteria for identifying small and medium-sized enterprises are specified in Article 6, Decree No. 39/2018/ ND-CP of the Government of Vietnam dated March 11, 2018, detailing a number of articles of the Law on Business Support for the small and medium-sized enterprises, mainly based on the number of employees and revenue. It might be difficult for large enterprises to effectively manage the organizational structure because of bureaucratic issues in the management structure; disagreements between shareholders and managers, these conflicts might lead to a lack of control. On the other hand, the results showed that small and medium-sized enterprises have gradually improved internal forces, operated more effectively, thus reducing the risk of bankruptcy (Harhoff, Stahl, \& Woywode, 1998; Salman \& Yazdanfar, 2012).

The analysis results showed that businesses operating in the manufacturing sector were at a high- er level of bankruptcy risk than those operating in the remaining sectors. In the data set of this study, enterprises operating in the manufacturing sector were mainly processing and aquaculture enterprises. This sector resulted higher profits but also accompanied by higher risks because of large investment in machinery, production lines, as the standards of food safety on the world market are required strictly.

When enterprises were classified by type of establishment, private enterprises were less risky than the others. In contrast, joint-stock companies were at higher risk. Joint-stock companies often have many members, and complex management arrangements require a strict management mechanism. It is also possible that due to disagreements between shareholders and managers, these conflicts will lead to ineffective control (Pi \& Timme, 1993). Besides non-financial factors that belong to the characteristics of the enterprises and the operators, financial factors also had direct impacts on bankruptcy risk.

For the financial factor group, the results of the regression analysis confirmed the previous studies. If the earnings before tax was low, the enterprise may have used the profits to pay off debt and interest or the business was inefficient leading to an increased risk to the business. Net profit/equity ratio (ROE) of enterprises had the same impact with the performance of enterprises. The research showed that enterprises with higher ROE had better performance and a lower level of bankruptcy risk. In addition, the higher earnings before interest and tax/total assets ratio (EBIT/TA), the better the profitability of assets of the business or the lower the risk of bankruptcy. The higher ratio of equity/ total debt proved the ability to raise capital by debt of the business as reflected by a lower level of risk.

\section{CONCLUSION AND RECOMMENDATIONS}

The study used Altman's Z-score as a tool to assess the bankruptcy risk of enterprises and the binary logistics model to measure the impact of financial and non-financial factors to bankruptcy risk of the business. Basically, these factors affected the bankruptcy risk and were confirmed by many previous empirical studies. However, in this research, two factors, including the age of the enterprise and the gender of the executor, did not have significant influence.

It is useful for managers, investors, and stakeholders to measure and predict the bankruptcy risk, which helps to identify business with potential risks in order to timely formulate the management policies. In 
addition, for commercial banks, when granting credit to businesses, it is also beneficial to refer to the impact of factors in the research to consider and decide to loan sizes.

From the perspective of corporate governance, the use of the $Z$-score and the evaluation of impact factors regularly to promptly detect and prevent the negative financial status of the business. Administrators need to decide to improve the management apparatus, business strategies to help businesses have a good direction, increase the financial stability.

In this research, the concept of bankruptcy was viewed as the financial status of an enterprise rather than an event (bankruptcy). This implied that the correct perception of bankruptcy risk will help businesses to have appropriate management solutions to improve and change their financial status in a more positive way. Limitations of this study: the lack of data available to track and verify the improvement and the probability of an event if the expected improvements were not implemented. Besides, the data set used in this study was only collected from the financial statements of enterprises in one region. Although Soc Trang province was located at average rank in the 2018 PCI of the country (VCCI and USAD, 2018), argues on differences by localities may be raised, which require the data of additional provinces to better reflect the situation of SMEs in Vietnam.

\section{ACKNOWLEDGMENT}

The authors would like to thank the Tax Department of Soc Trang Province for allowing us to access the financial reporting data of the businesses after ensuring the principles of anonymity and information protection.

\section{REFERENCES}

1. Akben-Selcuk, E. (2016). Does Firm Age Affect Profitability? Evidence from Turkey. International Journal of Economic Sciences, 5(3), 1-9. Retrieved from https://www.iises.net/international-journal-of-economic-sciences/ publication-detail-719

2. Alkhatib, K., \& Al Bzour, A. E. (2011). Predicting corporate bankruptcy of Jordanian listed companies: Using Altman and Kida Models. International Journal of Business and Management, 6(3), 208-215. https://doi.org/10.5539/ ijbm.v6n3p208

3. Aloy Niresh, J., \& Pratheepan, T. (2015). The Application of Altman's Z-Score Model in Predicting Bankruptcy: Evidence from the Trading Sector in Sri Lanka. International Journal of Business and Management, 10(12), 269-275. https://doi.org/10.5539/ ijbm.v10n12p269

4. Altman, E. I. (1968). Financial Ratios, Discriminant Analysis and the Prediction of Corporate Bankruptcy. Journal of Finance, 23(4), 589-609. https://doi. org/10.1111/j.1540-6261.1968. tb00843.x

5. Altman, E. I. (2018). A Fifty-Year Retrospective on Credit Risk Models, the Altman Z -Score Family of Models and their Applications to Financial Markets and Managerial Strategies. Journal of Credit Risk, 14(4). Retrieved from https://books. google.com.ua/books?id=mcq KDwAAQBAJ\&pg=PA189\&lp $\mathrm{g}=\mathrm{PA} 189 \& \mathrm{dq}=\mathrm{A}+$ Fifty-Year $+\mathrm{R}$ etrospective+on+Credit+Risk+ Models, + the + Altman $+Z+$-Scor e+Family+of+Models+and+the ir+Applications+to+Financial+ Markets+and+Managerial+Str ategies\&source=bl\&ots=_LW1ZAUwIK\&sig=ACfU3U0UgEY eR_EvZH6pxFa12MTjkEGZQ\& $\mathrm{hl}=\mathrm{ru \& sa}=\mathrm{X} \& \mathrm{ved}=2 \mathrm{ahUKEwj} \mathrm{Rtr}$ mX_ZbmAhVNiYsKHfPwBsoQ6 AEwAHoECAoQAQ\#v=onepage $\& \mathrm{q} \& \mathrm{f}=$ false
6. Altman, E. I. (2018). Applications of Distress Prediction Models What Have We Learned After 50 Years from the Z-Score Models? International Journal of Financial Studies, 6(3), 70. https://doi. org/10.3390/ijfs6030070

7. Altman, E. I., Haldeman, R. G., \& Narayanan, P. (1977). ZETA $^{\mathrm{TM}}$ analysis: A new model to identify bankruptcy risk of corporations. Journal of Banking \& Finance, 1(1), 29-54, https://doi. org/10.1016/0378-4266(77)90017-6

8. Altman, E., Hartzell, J., \& Peck, M. (1995). Emerging Markets Corporate Bonds - A Scoring System. Emerging Market Capital Flows, 391-400. Retrieved from https://link.springer.com/chapte r/10.1007/978-1-4615-6197-2_25

9. Amran, N. A. (2011). The Effect of Owner's Gender and Age to Firm Performance: A Review On Malaysian Public Listed Family Businesses. Journal of Global 
Business and Economics, 2(1), 104-116. Retrieved from https:// ideas.repec.org/a/grg/01biss/ v2y2011ilp104-116.html

10. Anh, L. C. H., \& Hang, N. T. (2012). Kiểm định mô hình chỉ số $\mathrm{Z}$ của Altman trong dự báo thất bại doanh nghiệp tại Việt Nam. Tạp chí Công nghệ Ngân hàng, 74 (in Vietnamese). Retrieved from http:// www.vjol.info/index.php/NH/article/view/15447

11. Apoorva, D. V., Curpod, S. P., \& Namratha (2019). Application of Altman Z Score Model on Selected Indian Companies to Predict Bankruptcy. International Journal of Business and Management Invention, 8(01), 77-82. Retrieved from http:// www.ijbmi.org/papers/Vol(8)1/Version-3/N0801037782.pdf

12. Beaver, W. H. (1966). Financial Ratios as Predictors of Failure. Journal of Accounting Research, 4, 71-111. https://doi. org/10.2307/2490173

13. Becchetti, L., \& Sierra, J. (2003). Bankruptcy risk and productive efficiency in manufacturing firms. Journal of Banking \& Finance, 27(11), 2099-2120. https://doi.org/10.1016/s03784266(02)00319-9

14. Bertrand, M., \& Schoar, A. (2003), Managing with Style: The Effect of Managers on Firm Policies. The Quarterly Journal of Economics, 118(4), 1169-1208, https://doi. org/10.1162/003355303322552775

15. Bhatt, S. N. (2012). Capital Structure and Turnaround Strategies using Altman's Z-Score Models. Asian Journal of Research in Business, Economics and Management, 2(7), 102113. Retrieved from https:// www.researchgate.net/publication/251349106_Capital_Structure_ and_Turnaround_Strategies_Using_Altman's_Z-Score_Models

16. Canh, N. P. (2014). Ưng dụng mô hình Z-score vào quản lý rủi ro tín dụng cho các ngân hàng thương mại Việt Nam. Tạp chí Phát triên và hội nhập, 15(25), 46-50 (in Vietnamese). Retrieved from https://static-cdn. uef.edu.vn/newsimg/tap-chiuef/2014-03-04-15/8.pdf
17. Cheng, L. T. W., Chan, R. Y. K., \& Leung, T. Y. (2010). Management demography and corporate performance: Evidence from China. International Business Review, 19(3), 261-275. https://doi.org/10.1016/j. ibusrev.2009.12.007

18. Cuong, N. T., \& Anh, P. T. (2010). Đánh giá nguy cơ phá sản của các doanh nghiệp chế biến thủy sản đang niêm yết trên thị trường chứng khoán Việt Nam. Tap chí Khoa học Công nghệ Thủy sản - Truờng Đại học Nha Trang, 02, 27-33 (in Vietnamese). Retrieved from https://www.researchgate.net/ profile/Nguyen_Thanh_Cuong2/ publication/283543013_Evaluating_bankruptcy_risk_of_seafood_ processing_enterprises_currently_ listed_on_Vietnam_stock_market/ links/564320d608ae9f9c13e02019/ Evaluating-bankruptcy-risk-ofseafood-processing-enterprisescurrently-listed-on-Vietnam-stockmarket.pdf

19. Duong, N. T. (2013). Phân tích rủi ro trong hoạt động ngân hang. Tạp chí Phát triên và hội nhập, 9(19), 29 39 (in Vietnamese). Retrieved from http://www.vjol.info/index.php/kttc/ article/viewFile/12279/11264

20. Hanh, D. M., \& Hoa, N. K. (2016). Ứng dụng mô hình Z-score và xếp hạng tín nhiệm doanh nghiệp vào quản lý rủi ro tín dụng tại các ngân hàng thương mại Việt Nam. Tạp chí Công thương, 07-Tháng 7/2016, 142-148 (in Vietnamese). Retrieved from https://tailieu.vn/ doc/ung-dung-mo-hinh-z-scorevao-quan-ly-rui-ro-tin-dung-chocac-ngan-hang-thuong-mai-vietnam-2132554.html

21. Hambrick, D. C., \& Mason, P. A. (1984). Upper Echelons: The Organization as a Reflection of Its Top Managers. Academy of Management Review, 9(2), 193-206. https://doi.org/10.2307/258434

22. Harhoff, D., Stahl, K., \& Woywode, M. (1998). Legal Form, Growth and Exit of West German Firms-Empirical Results for Manufacturing, Construction, Trade and Service Industries. Journal of Industrial Economics, 46(4), 453-488. https://doi. org/10.1111/1467-6451.00083
23. Hieu, N. V. (2015). Vận dụng mô hình "Z-Score" để kiểm định kết quả phân hạng tín dụng nội bộ và ước lượng xác suất vỡ nợ. Tạp chí Nghiên cứu Tài chính kế toán, 8(145), 26-30 (in Vietnamese).

24. Hsu, C. S., Kuo, L., \& Chang, B. G. (2013). Gender Difference in Profit Performance - Evidence from the Owners of Small Public Accounting Practices in Taiwan. Asian Journal of Finance \& Accounting, 5(1), 140159. https://doi.org/10.5296/ajfa. v5i1.3174

25. Huang, S. K. (2013). The Impact of CEO Characteristics on Corporate Sustainable Development. Corporate Social Responsibility and Environmental Management, 20(4), 234-244. https://doi.org/10.1002/ csr. 1295

26. Hussain, F., Ali, I., Ullah, S., \& Ali, M. (2014). Can Altman Z-score Model Predict Business failures in Pakistan? Evidence from Textile companies of Pakistan. Journal of Economics and Sustainable Development, 5(13), 10-115. Retrieved from https://www.iiste. org/Journals/index.php/JEDS/article/view/14273/14581

27. Inmyxai, S., \& Takahashi, Y. (2010). Performance Contrast and Its Determinants between Male and Female Headed Firms in Lao MSMEs. International Journal of Business and Management, 5(4), 37-52. https://doi.org/10.5539/ijbm. v5n4p37

28. Jalbert, T. (2002). Does School Matter? An Empirical Analysis Of CEO Education, Compensation, And Firm Performance. International Business \& Economics Research Journal, 1(1), 83-98. https:// doi.org/10.19030/iber.v1i1.3882

29. Jan, A. \& Marimuthu, M. (2015). Altman Model and Bankruptcy Profile of Islamic Banking Industry: A Comparative Analysis on Financial Performance. International Journal of Business and Management, 10(7), 110-119. http:// dx.doi.org/10.5539/ijbm.v10n7p110

30. Joh, S. W., \& Jung, J. Y. (2016). Top Managers' Academic Credentials and Firm Value. Asia-Pacific Journal of Financial Studies, 45(2), 185-221. https://doi.org/10.1111/ajfs.12127 
31. Khan, W. A., \& Vieito, J. P. (2013). Ceo gender and firm performance. Journal of Economics and Business, 67, 55-66. https://doi.org/10.1016/j. jeconbus.2013.01.003

32. Khoi, P. D., Loc, T. D., \& Danh, V. T. (2008), Tổng quan vê kinh tế tư nhân ở Đông bằng sông Củ̉u Long. Nhà xuất bản Giáo Dục, Cần Thơ (in Vietnamese).

33. Lubawa, G., \& Louangrath, P. (2016). Using Altman Z-Score to Assess the Financial Effects of Multiple Loans on SMEs. International Journal of Research and Methodology in Social Science, 2(1), 63-88. https://doi. org/10.5281/zenodo.1315187

34. Nghi, N. Q., \& Nam, M. V. (2011). Các nhân tố ảnh hưởng đến hiệu quả hoạt động kinh doanh của doanh nghiệp nhỏ và vừa ở Thành phố Cần Thơ. Tạp chí Khoa học Trường Đại học Cân Thơ, 19, 122129 (in Vietnamese). Retrieved from https://sj.ctu.edu.vn/ql/docgia/ download/baibao-5576/trongtruong_so19b_15.pdf

35. Odibi, I., Basit, A., \& Hassan, Z. (2015). Bankruptcy prediction using Altman z-score model: A case of public listed manufacturing companies in Malaysia. International Journal of Accounting and Business Management, 3(2), 178-186. https://doi.org/10.24924/ ijabm/2015.11/v3.iss2/178.186

36. Omondi, M. M., \& Muturi, W. (2013). Factors Affecting the Financial Performance of Listed Companies at the Nairobi Securities Exchange in Kenya. Research Journal of Finance and Accounting, 4(15), 99-104. Retrieved from https://www.iiste.org/Journals/index. php/RJFA/article/view/8309

37. Park, Y., Shin, J., \& Kim, T. (2009). Firm size, age, industrial networking, and growth: a case of the Korean manufacturing industry. Small Business Economics, 35(2), 153-168. https://doi.org/10.1007/ s11187-009-9177-7

38. Pi, L., \& Timme, S. G. (1993). Corporate Control and Bank Efficiency. Journal of Banking and Finance, 2(3), 515-530. https://doi. org/10.1016/0378-4266(93)90050-n

39. Plandor, D., \& Landryova, L. (2012) Bankruptcy and Financial Standing
Models Application for SMEs. The Seventh International Conference on Software Engineering Advances, 161-164. Retrieved from https:// www.thinkmind.org/index.php?vie $\mathrm{w}=$ article\&articleid=icsea_2012_6_ 40_10455

40. Pradhan, R. (2014). Z-Score Estimation for Indian Banking Sector. International Journal of Trade, Economics and Finance, 5(6), 516-520. https://doi.org/10.7763/ ijtef.2014.v5.425

41. Ramana, V., Azash, S. Md., \& Ramakrishnaiah, K. (2012). Financial performance and predicting the risk of bankruptcy: A case of selected cement companies in India. International Journal of Public administration and Management research, 1(1), 4056. Retrieved from http://rcmss. com/1ijpamr/FINANCIAL\%20 PERFORMANCE\%20AND\%20 PREDICTING\%20THE\%20 RISK\%20OF\%20BANKRUPTCY_\%20A\%20CASE\%20OF\%20SELECTED\%20CEMENT\%20COMPANIES\%20IN\%20INDIA.pdf

42. Saini, V. (2018). A Study on Financial Performance of Tata Chemicals in Fertilizer Sector: A 'Z' Score Approach. International Journal of Basic and Applied Research, 8(9), 280-286.

43. Salman, A. K., \& Yazdanfar, D. (2012). Profitability in Swedish Micro Firms: A Quantile Regression Approach. International Business Research, 5(8), 94-106. http://dx.doi. org/10.5539/ibr.v5n8p94

44. Selassie, E. G., Tarekegn, G., \& Ufo, A. (2016). Analysis of Financial Distress and its Determinants in Selected SMEs in Wolaita Zone. Global Journal of Management and Business Research: C Finance, 16(8), 35-41. Retrieved from https:// globaljournals.org/item/6446analysis-of-financial-distress-andits-determinants-in-selected-smesin-wolaita-zone

45. Sulphey, M. M., \& Nisa, S. (2013). The Analytical Implication of Altman's Z Score Analysis of BSE Listed Small Cap Companies. Global Journal of Commerce \& Management Perspective, 2(4), 145-155. Retrieved from https://www.researchgate.net/ publication/299175808_THE_ ANALYTICAL_IMPLICA-

TION_OF_ALTMAN'S_Z_SCORE_ ANALYSIS_OF_BSE_LISTED SMALL_CAP_COMPANIES

46. Taffler, R. J. (1983). The Assessment of Company solvency and Performance Using a Statistical Model. Accounting and Business Research, 13(52), 295-307. https:// doi.org/10.1080/00014788.1983.9 729767

47. Tam, K. Y., \& Kiang, M. Y. (1992). Managerial Applications of Neural Networks: The Case of Bank Failure Predictions. Management Science, 38(7), 926-947. https://doi. org/10.1287/mnsc.38.7.926

48. Tan, N. M., Danh, V. T., \& Ngan, T. T. (2015). Các nhân tố ảnh hưởng đến hiệu quả hoạt động kinh doanh của doanh nghiệp nhỏ và vừa tại tỉnh Bạc Liêu. Tap chí Khoa học Truiơng Đại học Cân Thơ, 38, 34-40 (in Vietnamese). Retrieved from https://sj.ctu.edu.vn/ql/docgia/ download/baibao-14156/05-KTNGUYEN\%20MINH\%20TAN(3440).pdf

49. Van, P. T. T. (2016). Xem xét khả năng sử dưng mô hình Z-score trong đánh giá tình hình hoạt động của doanh nghiẹp Việt Nam (in Vietnamese). Retrieved from http://nif.mof.gov.vn/webcenter/ portal/vclvcstc/r/m/ncvtd/ncvtd chitiet;jsessionid=0bP_RRp4Wx31 IRu2MJWqq7ZNX0IkRjJcXEo8N lYkg9hbRDE4Nqgu!1398501639!907543176? dDocName=MOFUC M087420\&dID=10972\&_afrLoop $=56264399402728822 \# ! \% 40 \% 40 \%$ 3FdID\%3D10972\%26_afrLoop\%3 D56264399402728822\%26dDocNa me\%3DMOFUCM087420\%26_adf. ctrl-state\%3Dheya63yrj_4 (accessed on January 19, 2019).

50. VCCI (2018). United States Agency for International Development Provincial Competitiveness Index Report of Vietnam, 14, 23 24. Retrieved from http://eng. pcivietnam.org/wp-content/ uploads/2019/03/BaoCaoPCI2018_ ENG.pdf 